\title{
CORRESPONDENCE
}

Continued from page 452

During a relatively short period, many of the above demands were introduced practically although not by law. In particular the presidium of the academy and the chancellors and deans in almost all universities were chosen in a truly democratic way.

It is significant that most of those elected were politically inactive before 1980 and of moderate views, and gained their authority solely on the basis of their scientific achievements. Thus the elected people can be seen as truly representative of a scientific community which is not heroic but truthful, which follows directives but recognizes that the political direction of science has damaging effects.

It can be argued that a similar attitude is typical of "normal" scientific communities. But the Polish one is not "normal". Its older members endured the Nazi holocaust or harsh life in remote Soviet provinces; their students started their careers during the period of the Stalin cult with its brainwashing machinery. This community suffered the wave of repressions and purges in 1968 followed by the liquidation of the remnants of academic freedoms. It was corrupted during the past ten years of mild but effective "sovietization" Thus it was encouraging to see that the old ideals of scientific freedom, so often declared to be outdated, are so deeply rooted in the bulk of this community and that it is ready to support democratic changes.

Surely the power of the reformers of the scientific establishment rested not only, and not even mainly, on the social forces in their own home but on the forces of an awakening society.

Perhaps much more could have been achieved. There were too many useless meetings, endless and inconclusive discussions about the new structure of science or about formulations of new constitutions. We were drunk after taking too large a draught of democracy and were not yet ready to use it effectively.

Most of the staff of the academy and universities joined Solidarity. But surprisingly, during 1980-81, students were less eager to follow this movement, although a large number of new student organizations appeared. Even the most influential of these, Niezalezne Zrzeszenie Studentow (NZS Independent Student Association) was joined by fewer than 20 per cent of the students.

The main action of NZS was the proclamation in October 1981 of a general strike in protest at the halting of legislative procedures concerned with the new progressive law of higher education and in support of the protest of the Radom branch of NZS and Solidarity against the way the rector of Radom Polytechnic had been elected. This strike was joined by a most of the schools of higher education in the country. In spite of the efforts of Solidarity, the Church and the Council of Chancellors of the Polish Schools of Higher Education, this strike was continued after the strikers' first demand was conceded. A few days before martial law was declared the strike broke down. In January 1982 NZS was dissolved by the authorities.

The era of Solidarity - understood here not as a name of this particular organization with its achievements and follies but as synonymous with the greatest all-national movement in our history - is over. Solidarity is for the time being defeated. But it should be underlined that to the same or an even larger extent the communists who ruled the country for more than 35 years have also been defeated. The political regime proved itself to be not only ineffective and acting against the will of the people, but irreparable and wholly dependent on external powers. In a sense only the Russians won the battle, by finding a way of solving the problem without needing to use their own troops.

The battle is lost, the war is not. It is still the common belief that something very important happened which will influence our future, and perhaps not only ours. I have in mind not only economic and social changes but the changes of spirit of those who rule and those who are ruled - these changes are not as abstract as the word spirit suggests.

Just after the declaration of martial law there was a wave of protests. This wave did not bypass scientific institutions. As yet we do not have a full account of what happened, but we know about the strikes of a few institutes of the academy in the Staszic Palace in the centre of Warsaw which were terminated by force; about a letter of protest signed by more than 300 scientists in the Institute of Chemical Physics; about the strike in the Institute of Nuclear Research in Swierk near Warsaw followed by arrests and trials of several scientists.

The work of all schools of higher education was immediately suspended, but there was a protest of teachers and students in Wroclaw Technical University where several people including the vice-chancellor were badly beaten. We know about strikes in the Warsaw Agricultural Academy, the Mining Academy in Krakow, and the University of Lublin. The senate of the oldest Polish University, the Jagiellonian University in Kraków, sent a letter of protest with a demand for the release of the arrested people.

The number of students and staff arrested is not known. In the University of Warsaw more than 40 people were either interned or arrested. An overall estimate based on this figure might be misleading because the University of Warsaw has been under the special care of the authorities for many years.

Young people, those between 18 and 25, seem likely to be the main losers: they will lose if they decide to fight, because there is no chance of winning; they will lose if they decide to give up, because of the devastating effects of conformity. The generation gap between them and us, already felt during their strike, seems to be widening. The students prefer to follow the heroic pattern of the young generation duing World War II and do not want to give up the only experience they have gained by their own efforts, the experience of the past year.

As yet almost nothing of importance has been changed in scientific institutions by martial law. True, in all universities, as well as in all schools and in most institutes, there are military commissars who are acting not directly but through the existing administration.

But we are only at the beginning of the new road. It seems almost certain that many teachers at all levels will lose their jobs. In secondary schools and in all institutions of public administration the authorities have already demanded written declarations of loyalty, and those who refuse to sign are fired. A similar type of verification of staff and students is expected in the universities, and it will lead to the replacement of all elected bodies by nominees. Many scientists will probably lose the opportunity to continue their scientific work, as happened in

Czechoslovakia.

The outlook is not optimistic. We may expect the worst members of the scientific community to move to the front of the scene. It is a well established tradition to ignore such people; but in the present situation this should not be followed. Scientists who try to abolish what has been achieved should be named and ostracized by the scientific community all over the world. And those who suffer for the defence of scientific freedom should feel the moral, and perhaps also material, support of all their friends and colleagues, first of all here in Poland, but also abroad. If we fail to condemn the former and to provide effective support for the latter our defeat may become a catastrophe.

\section{Not the baron}

SIR - Sir Peter Medawar asks in a book review (Nature 28 January, p.351) "was it not Cuvier who named a fossil ichthyosaurus Homo diluvii testis . . .?". It was not: the fossil (now on display in the Teyler Museum, Haarlem) was so called by J.J. Scheuchzer $(1726)^{1}$. Scheuchzer also describes the fossil in a letter published in Philosophical

Transactions of the Royal Society of London ${ }^{2}$ Baron Cuvier, visiting the Netherlands as a member of a commission sent by Napoleon, confirmed his own identification of the fossil as a giant salamander by carefully removing some of the matrix to reveal the forelimbs (illustrated in Cuvier, 1824) ${ }^{3}$

Julie Hamilton

University of Oxford, $U K$

\footnotetext{
. Scheuchzer, J.J. Homo Diluvii Testis et theoskopos. (Tiguri 1726)

2. Scheuchzer, J.J. Phil. Trans. R. Soc. 24, 38-39 (1726-27)

3. Cuvier, G. Recherches sur les Ossemens Fossiles 1st Edn,
} Vol. V, 431-434 and Plate XXVI (Paris, 1824).

\section{US spoken}

SIR - The editor's leftist leanings have been quite evident of late, but isn't the sentence (Nature 14 January, p.86), "United States users of the telephone will most immediately discover that it costs them more to use the local telephone service as if it were unmetered water"' (italics mine), not only lacking in lucidity but also bending a bit too far left when it employs "United States" as a general adjective? We are Americans, by God!, not "United Statesers" - and the adjective is American! I and others proud of America deplore your emasculation of our rightfu name, especially when it is to indulge the arrogance of leftists in Nicaragua, Mexico, or wherever, who never refer to themselves as "Americans", but at the same time, with a malevolent dog-in-the-manger attitude, wish to deny us that distinctive title.

EDWIN E. ROSENBLUM

New York, America

What about the Canadians? Editor 